\title{
Communication
}

[Comunicação]

\section{Polymorphisms of leptin, $\beta$-lactoglobulin and pituitary transcription factor have no effect on milk characteristics in crossbred cows}

\author{
[Polimorfismos da leptina, $\beta$-lactoglobulina e fator de transcrição da hipófise não afetam \\ as características do leite em vacas mestiças] \\ J.B. Ferreira ${ }^{1}$, M.M. Guilhermino ${ }^{2}$, J.H.G.M. Leite ${ }^{1}$, J.E.R. Sousa ${ }^{1}$, \\ B.V.S. Araújo ${ }^{1}$, A.M. Vasconcelos ${ }^{3}$, M.A.C. Lara ${ }^{4}$, D.A.E. Façanha \\ ${ }^{1}$ Universidade Federal Rural do Semiárido - Mossoró, RN \\ ${ }^{2}$ Universidade Federal do Rio Grande do Norte - Natal, RN \\ ${ }^{3}$ Universidade Estadual Vale do Acaraú - Sobral, CE \\ J.B. Ferreira1 \\ https://orcid.org/0000-0002-5927-0545 \\ M.M. Guilhermino2 \\ https://orcid.org/0000-0002-5935-2153 \\ J.H.G.M. Leite1 \\ https://orcid.org/0000-0002-8195-0846 \\ J.E.R. Sousa1, \\ https://orcid.org/0000-0002-6565-3403 \\ B.V.S. Araújo 1 \\ https://orcid.org/0000-0003-1964-4706 \\ A.M. Vasconcelos 3 \\ https://orcid.org/0000-0002-9690-974X \\ M.A.C. Lara4 \\ https://orcid.org/0000-0001-5144-8858 \\ ${ }^{4}$ Instituto de Zootecnia - Agência Paulista de Tecnologia dos Agronegócios - São Paulo, SP D.A.E. Façanhal
}

Milk production systems installed in the Brazilian semiarid region are used on a large scale, in which the European breeds specialized in milk production are hybridized with zebu breeds more suited to a climate with semiarid conditions (Façanha et al., 2017). The result of this crossbreeding produces animals that are less productive, although better adapted to the tropics, which has increased the productivity and viability of dairy farming in the semiarid northeast. Allelic identification of the different genotypes of dairy cows, using molecular biology techniques, is used to make adjustments in genetic improvement programs, directing crosses of different genetic groups for more efficient gains in animal production systems.

The strategy of detecting genetic polymorphisms associated with genes which are important for a studied trait has been successfully employed (Hax et al., 2017). For milk production, polymorphisms of the $\kappa$-casein and $\beta$ lactoglobulin genes stand out. According to Otaviano et al. (2008) and Freitas et al. (2012), casein $(\mathrm{S} 1 \alpha, \mathrm{S} 2 \alpha$ and $\beta)$ and serum proteins $(\beta$ lactoglobulin and $\alpha$-lactalbumin) are associated with increased protein levels in milk. Similarly, other polymorphisms have been investigated, for example, some single nucleotide polymorphisms (SNPs) in leptin genes (Madeja et al., 2004) and pituitary transcription factor or PIT1 (Renaville et al., 1997), because they have significant effects on milk production, feed conversion, weight gain, meat tenderness and subcutaneous fat deposition. In many countries, these studies are well advanced in the Holsten breed. On the other hand, for dairy zebu, there is still a gap. Today, only Australia and the United States are researching the Bos indicus group, giving greater importance to these breeds, especially the Brahman breed. Currently, little is known about the effects of crossbreeding between Holstein and Guzerá cows, kept in a hot climate and a semiarid region.

The aim of the present work was to identify genetic polymorphisms of leptin, $\beta$-lactoglobulin and pituitary transcription factor (PIT1) and to evaluate their effects on the chemical composition and somatic cell count of milk from crossbred dairy cows. All procedures performed with the animals of the present experiment were in accordance with the ethical standards stablished be the committee of the Universidade Federal Rural do Semiárido, UFERSA $\left(\mathrm{n}^{\circ}\right.$. 23091.003895/2014-71).

We obtained 291 blood samples for DNA extraction and milk samples from crossbred cows. The samples were of three genetic groups: $1 / 2$, Holstein x Guzerá $(n=42), 3 / 4$ Holstein $x$ Guzerá (83) and $7 / 8$ Holstein x Guzerá (166). Whole blood samples were collected into EDTA tubes by puncturing the mammary vein. For

Recebido em 3 de maio de 2018

Aceito em 20 de novembro de 2018

E-mail: jjosielborges@hotmail.com 
genomic DNA extraction, we used the protocol according to Montgomery and Sise (1990). The amplification reactions of the leptin, $\beta$ lactoglobulin and PIT1 genes were conducted in a thermocycler. Then, $5 \mu 1$ aliquots of the amplified product were digested with restriction enzymes for restriction sites found in each marker (Table 1). The resulting fragments were separated by electrophoresis in tris-borate-EDTA (TBE) in $10 \%$ polyacrylamide gel and stained with silver nitrate. The animal genotype was determined by the analysis of fragment size reported as base pairs.

Table 1. Primers, Fragment length, thermal cycle, enzymes, unit and enzyme digestion used to genotype leptine, $\beta$-lactoglobulina and pituitary transcription factor (PIT1) genes

\begin{tabular}{|c|c|c|c|c|c|}
\hline Gene & $\begin{array}{c}\text { Ampli } \\
\text { con }\end{array}$ & Thermal cycle & Enzyme & Unit & Digestion \\
\hline $\begin{array}{l}\text { Leptin primers } \\
\text { FW: 5'- } \\
\text { ATGCGCTGTGGACCCCTGTATC-3' } \\
\text { RV: 5'- } \\
\text { ATGCGCTGTGGACCCCTGTATC-3, }\end{array}$ & $94 b p$ & $\begin{array}{c}95^{\circ} \mathrm{C} \text { per } 5 \min \text { (initial } \\
\text { denaturation), } 40 \text { cycles } \\
94^{\circ} \mathrm{C} \text { per } 45 \mathrm{~s}, 52^{\circ} \mathrm{C} \text { per } 45 \mathrm{~s}, \\
72^{\circ} \mathrm{C} \text { per } 55 \mathrm{~s}, 72^{\circ} \mathrm{C} \text { per } \\
3 \text { min (final extension) }\end{array}$ & $K p n 2 I^{1}$ & $2 \mathrm{U}$ & $55^{\circ} \mathrm{C} 3 \mathrm{~h}$ \\
\hline $\begin{array}{l}\beta \text {-lactoglobulin primers } \\
\text { FW: 5'- } \\
\text { GTCCTTGTGCTGGACACCGACTAC } \\
\text { A-3' } \\
\text { RV: 5'- } \\
\text { CAGGACACCGGCTCCTGGTATATG } \\
\text { A-3' }\end{array}$ & $262 b p$ & $\begin{array}{c}95^{\circ} \mathrm{C} \text { per } 3 \min \text { (initial } \\
\text { denaturation), } 35 \text { cycles } \\
95^{\circ} \mathrm{C} \text { per } 40 \mathrm{~s}, 64^{\circ} \mathrm{C} \text { per } 40 \mathrm{~s}, \\
72^{\circ} \mathrm{C} \text { per } 30 \mathrm{~s}, 72^{\circ} \mathrm{C} \text { per } \\
10 \mathrm{~min} \text { (final extension) }\end{array}$ & HaelII $^{2}$ & $6 \mathrm{U}$ & $37^{\circ} \mathrm{C} 4 \mathrm{~h}$ \\
\hline $\begin{array}{l}\text { PIT1 primers } \\
\text { FW: 5'- } \\
\text { GTGGTGAGGGTTTGGTTTTG-3' } \\
\text { RV: 5'- } \\
\text { TGGCTGGAGAAGAGAAAGGA-3' }\end{array}$ & $168 b p$ & $\begin{array}{c}95^{\circ} \mathrm{C} \text { per } 2 \mathrm{~min} \text { (initial } \\
\text { denaturation), } 35 \text { cycles } \\
94^{\circ} \mathrm{C} \text { per } 45 \mathrm{~s}, 56^{\circ} \mathrm{C} \text { per } 45 \mathrm{~s}, \\
72^{\circ} \mathrm{C} \text { per } 1 \mathrm{~m}, 72^{\circ} \mathrm{C} \text { per } \\
10 \mathrm{~min} \text { (final extension) }\end{array}$ & $\operatorname{Hinf} \mathrm{I}^{1}$ & $4 \mathrm{U}$ & $37^{\circ} \mathrm{C} 6 \mathrm{~h}$ \\
\hline
\end{tabular}

Based on the results of the PCR/RFLP analyses, the genotypes of each animal were identified. The estimates of allele and genotype frequencies were calculated using the GENEPOP software version 1.2. The genotypic and allelic frequencies of the population sample for the gene fragment of leptin, $\beta$-lactoglobulin and PIT1 were established by the following equations: $x_{i}=\frac{2 n_{i i}+\sum n_{i j}}{2 n}$ and $x_{i i}=\frac{n_{i i}}{n}$, where $n_{i i}$ and $n_{i j}$ correspond to the number of homozygotes and heterozygotes observed in gene $i$, respectively; $n$ corresponds to the total number of individuals (Otaviano et al., 2008). The Hardy-Weinberg equilibrium was tested for each gene to according Falconer and Mackay (1996).

Two milk samples were collected after predipping sterile containers containing preservatives that varied according to the type of analysis. The preservative Bropanol ${ }^{\circledR}$ was used for the somatic cell composition and counting analyses and the preservative Azidiol ${ }^{\circledR}$ as used for total bacterial counts. The analysis of milk composition (fat, protein, lactose and non-fat dry extract), somatic cell count and yields was also performed.

The genetic groups and the genetic polymorphisms for each gene (leptin, $\beta$ lactoglobulin and PIT1) were used as fixed effects in the analysis of variance (t-test). In addition, the interaction between the two fixed effects was also evaluated.

For the leptin gene, the amplified and digested product with the restriction enzyme Kpn2I generated two 75 and 19bp fragments for the C allele with a restriction site. CT heterozygotes showed fragments of 94,75 and 19bp and the T allele showed only a fragment of $94 \mathrm{bp}$, because it does not contain a restriction site for Kpn2I.

For the $\beta$-lactoglobulin gene, the fragment digestion obtained by the PCR-RFLP technique showed a restriction polymorphism for the 
HaeIII enzyme. The AA genotype was characterized by the presence of two fragments (153 and 109bp), AB by the presence of four fragments $(153,109,74$ and 79bp) and the BB genotype by the presence of three fragments (109, 79 and $74 \mathrm{bp})$.

In the study of the variability of the PIT1 gene, a fragment of $168 \mathrm{bp}$ was analyzed using the Hinf 1 enzyme, which allowed for the identification of the (+) and (-) alleles. Only the (+) allele presented a restriction site for Hinf1, characterized by the presence of two fragments with 96 and 76bp. Homozygous $(+/+)$ animals were identified by the two (-) band patterns, corresponding to 96 and 76bp fragments. The $(+/-)$ heterozygotes were indicated by three bands
(168, 96 and 76pb) and the (-/-) homozygotes by a single band (168bp).

The allele frequencies were described together with the genotype frequencies according to the three genetic groups studied (Table 2). For the allele frequencies of leptin, the absence of the CC genotype was found in the group of $7 / 8$ Holstein $\mathrm{x}$ Guzerá animals, demonstrating an imbalance in the Hardy-Weinberg equilibrium $(\mathrm{P}<0.04)$. The same observation was true for PIT1, where the TT allele frequency in the group of $1 / 2$ Holstein $x$ Guzerá animals was equal to zero. For PIT in particular, a Hardy-Weinberg imbalance was shown all three groups of animals $(\mathrm{P}<0.03)$.

Table 2. Allele and genotype frequency for leptin, $\beta$-lactoglobulin and pituitary transcription factor (PIT1) polymorphisms for crossbred dairy cows

\begin{tabular}{|c|c|c|c|c|c|c|}
\hline Genotype & \multicolumn{3}{|c|}{ Allele frequency } & \multicolumn{3}{|c|}{ Genotype frequency } \\
\hline Leptin & $\mathrm{C}$ & $\mathrm{T}$ & P-value & $\mathrm{C} / \mathrm{C}$ & $\mathrm{C} / \mathrm{T}$ & $\mathrm{T} / \mathrm{T}$ \\
\hline $1 / 2$ Holstein x Guzerá & 0.6 & 0.4 & & 0.10 & 0.05 & 0.80 \\
\hline $3 / 4$ Holstein x Guzerá & 0.4 & 0.6 & & 0.08 & 0.74 & 0.16 \\
\hline 7/8 Holstein x Guzerá & 0.2 & 0.8 & & 0 & 0.40 & 0.60 \\
\hline Hardy-Weinberg equilibrium & & & 0.004 & & & \\
\hline$\beta$-lactoglobulin & A & $\mathrm{B}$ & & $\mathrm{A} / \mathrm{A}$ & $\mathrm{A} / \mathrm{B}$ & $\mathrm{B} / \mathrm{B}$ \\
\hline $1 / 2$ Holstein x Guzerá & 0.4 & 0.6 & & 0.10 & 0.57 & 0.31 \\
\hline $3 / 4$ Holstein x Guzerá & 0.4 & 0.6 & & 0.12 & 0.52 & 0.34 \\
\hline 7/8 Holstein x Guzerá & 0.5 & 0.5 & & 0.33 & 0.33 & 0.33 \\
\hline Hardy-Weinberg equilibrium & & & $<0.001$ & & & \\
\hline PIT1 & + & - & & $+/+$ & $+/-$ & $-1-$ \\
\hline $1 / 2$ Holstein x Guzerá & 0.9 & 0.1 & & 0.90 & 0.10 & 0.02 \\
\hline $3 / 4$ Holstein x Guzerá & 0.8 & 0.2 & & 0.64 & 0.29 & 0.05 \\
\hline $7 / 8$ Holstein x Guzerá & 0.7 & 0.2 & & 0.57 & 0.42 & 0 \\
\hline Hardy-Weinberg equilibrium & & & 0.003 & & & \\
\hline
\end{tabular}

$\mathrm{P}$-value for the test for Hardy-Weinberg equilibrium, in which $\mathrm{P}<0.05$ indicates that the population being sampled is not Hardy-Weinberg equilibrium.

Buchanan et al. (2002) reported the frequency of the $\mathrm{T}$ allele in cattle of the Angus (0.5), Charolais (0.3), Hereford (0.5) and Simental (0.3) breeds. According to Konfortov et al. (1999), the T allele is probably present in the taurine breed at a frequency close to 0.4 and does not appear in the Indian breed, where the $\mathrm{C}$ allele appears to be fixed. The present study suggests the predominance of taurine genes in the investigated crossbred dairy cow population, since the frequency of $\mathrm{T}$ was similar to that found in European breeds. $\beta$-lactoglobulin is encoded by a single locus in autosomal genes; twelve allelic variants have been reported for this gene, with $\mathrm{A}$ and $\mathrm{B}$ being the most frequent variants in domestic cattle. In the present study, the populations were in HardyWeinberg equilibrium ( $\mathrm{P}>0.05$ ) and no change was found in relation to these genes, resembling the results found by Veli and Rivas (2010) in populations of crossbred dairy cows.

The results obtained for genotypes of crossbred dairy cows no showed significant differences $(\mathrm{P}<$ 0.05 ) in milk composition and quality variables 
(Table 3). However, other studies have associated some leptin polymorphisms with milk production characteristics (Madeja et al., 2004) with significant effects $(\mathrm{P}<0.01)$ of the TT genotype (HphI polymorphism) on the genetic value of some characteristics, such as milk, fat and protein.

Table 3. Averages obtained for the characteristics: fat, protein, lactose, non-fat dry extract (NFDE), somatic cell count (SCC) and milk yield of genotype for leptin, $\beta$-lactoglobulin and pituitary transcription factor (PIT1) polymorphisms for crossbreed dairy cows

\begin{tabular}{|c|c|c|c|c|c|c|}
\hline Genotype & Fat, $\%$ & Protein, $\%$ & Lactose, \% & NFDE, $\%$ & $\mathrm{SCC}, \times 10^{3} \mathrm{ml}$ & $\begin{array}{c}\text { Milk yield, } \\
\text { L/day }^{-1}\end{array}$ \\
\hline \multicolumn{7}{|l|}{ Leptin } \\
\hline $\mathrm{C} / \mathrm{C}$ & 1.25 & 2.98 & 4.09 & 8.34 & 2.65 & 8.56 \\
\hline $\mathrm{C} / \mathrm{T}$ & 1.58 & 3.18 & 4.11 & 8.44 & 2.67 & 9.40 \\
\hline $\mathrm{T} / \mathrm{T}$ & 1.14 & 3.03 & 4.46 & 8.01 & 2.66 & 8.60 \\
\hline \multicolumn{7}{|c|}{$\beta$-lactoglobulin } \\
\hline $\mathrm{A} / \mathrm{A}$ & 1.82 & 3.19 & 4.10 & 8.05 & 2.59 & 10.65 \\
\hline $\mathrm{A} / \mathrm{B}$ & 1.30 & 3.04 & 4.36 & 8.31 & 2.61 & 9.43 \\
\hline $\mathrm{B} / \mathrm{B}$ & 1.55 & 3.19 & 4.19 & 8.31 & 2.54 & 9.20 \\
\hline \multicolumn{7}{|l|}{ PIT1 } \\
\hline$+/+$ & 1.56 & 3.13 & 4.28 & 8.34 & 2.58 & 10.02 \\
\hline$+/-$ & 0.95 & 2.96 & 4.25 & 8.11 & 2.20 & 9,34 \\
\hline$-/-$ & 1.04 & 3.02 & 4.30 & 8.40 & 2.34 & 9.79 \\
\hline
\end{tabular}

Averages of each genotype compared between rows in the same column.

Although genetic variants $\mathrm{A}$ and $\mathrm{B}$ of $\beta$ lactoglobulin are most strongly related to milk yield and fat production (Bonfatti et al., 2010 and Freitas et al., 2012), the variation between the means found in this study was minimal and there was no difference between the genotypes.

In the present study, it was expected that most of the composition variables would vary among the genotypes. It is already known that crosses give rise to animals with both phenotypic and genotypic characteristics. However, we found in this study that polymorphisms leptin, $\beta$ - lactoglobulin and PIT1 do not influence the composition and quality of milk from $1 / 2,3 / 4$ and $7 / 8$ Holstein $x$ Guzerá cows kept in a hot climate.

\section{ACKNOWLEDGMENTS}

Thanks to Canhotinho farm and Instituto de Zootecnia (Institute of Animal Science), IZ.

Keywords: dairy cows, animal production, genetic resources, Guzerá, Holsten

\section{RESUMO}

O objetivo deste trabalho foi identificar polimorfismos genéticos de leptina, $\beta$-lactoglobulina e fator de transcrição pituitária (PIT1) e avaliar seus efeitos na composição química e na contagem de células somáticas de leite de vacas leiteiras mestiças que vivem em um clima quente. Um total de 291 vacas leiteiras mestiças foram investigadas. Foram coletadas amostras de sangue para extração de DNA $e$ amostras de leite. As amostras foram classificadas em três grupos genéticos: 1/2 (42), 3/4 (83) e 7/8 (166) Holandês x Guzerá. As frequências de alelos e genótipos foram determinadas e o equilíbrio HardyWeinberg foi avaliado. Foram realizadas análises da composição do leite (gordura, proteína, lactose e extracto seco desengordurado), contagem de células somáticas e rendimento leiteiro. Os grupos genéticos e os polimorfismos genéticos para cada gene foram utilizados como efeitos fixos na análise. $O$ único polimorfismo encontrado em equilíbrio de Hardy-Weinberg foi para o genótipo da $\beta$ lactoglobulina. No presente estudo, era esperado que a maioria das variáveis de composição variasse entre os genótipos. Já se sabe que os cruzamentos dão origem a animais com características fenotípicas 
e genotípicas. No entanto, os polimorfismos não influenciaram a composição e a qualidade do leite nas vacas $1 / 2,3 / 4$ e $7 / 8$ Holstein x Guzerá mantidas em um clima quente.

Palavras-chave: vacas leiteiras, produção animal, recursos genéticos, Guzerá, Holandês

\section{REFERENCES}

BONFATTI, V.; DI MARTINO, G.; CECCHINATO, A. et al. Effects of $\beta$ - $\kappa$-casein (CSN2-CSN3) haplotypes and $\beta$-lactoglobulin (BLG) genotypes on milk production traits and detailed protein composition of individual milk of Simmental cows. J. Dairy Sci., v.93, p.37973808, 2010.

BUCHANAN, F.C.; FITZSIMMONS, C.J.; VAN KESSEL, A.A. et al. Association of a missense mutation in the bovine leptin gene with carcass fat content and leptin mRNA. Gent. Sel. Evol., v.34, p.105-116, 2002.

FAÇANHA, D.A.E.; FERREIRA, J.B.; SOTOBLANCO, B. et al. Multivariate approach to milk production and some physiological traits of crossbred dairy cows. Semin. Ciênc. Agrár., v.38, p.2723-2728, 2017.

FALCONER, D.S.; MACKEY, T.F.C. (Eds.). Introduction to quantitative genetics. Edinburgh: Longman Group Limited, 1996. 464p.

FREITAS, S.F.A.; REINOSA, O.U.; BARBOSA, S.B.P. Polimorfismo genético da beta-lactoglobulina em bovinos holando-gir no estado de Pernambuco. Rev. Salud Anim., v.34, p.13-20, 2012.

HAX, L.T.; SCHNEIDER, A.; JACOMETO, C.B. et al. Association between polymorphisms in somatotropic axis genes and fertility of Holstein dairy cows. Theriogenology, v.88, p.6772, 2017.

KONFORTOV, B.A.; LICENCE, V.E.; MILLER, J.R. Re-sequecing of DNA from a diverse panel of cattle reveals a high level of polymorphism in both intron and exon. Mamm. Genome, v.10, p.1142-1145, 1999.
LARA, M.A.C.; PINATTI, E.; FARIA, M.H. et al. Polimorfismo do gene leptina (SNP305) em bovinos e sua implicação na maciez de carne. Actas Iberoam. Conserv. Anim., v.1, p.195-198, 2011.

MADEJA, Z.; ADAMOWICZ, T.; CHMURZYNSKA, A. et al. Effect of leptin gene polymorphisms on breeding value for milk production traits. J. Dairy Sci., v.87, p.39253927, 2004.

MAIGNANALAKSHMI, S.; MAHALINGA NAINAR, A. PCR-RFLP Analysis of Betalactoglobulin gene in Murrah Buffaloes. J. Vet. Anim. Sci., v.5, p.194-197, 2009.

MONTGOMERY, G.W.; SISE, J.A. Extraction of DNA from sheep white blood cells. Aust. J. Agric. Res., v.33, p.437-441, 1990.

OTAVIANO, A.R.; LIMA, A.L.F.; LAUREANO, M.M.M. et al. $\beta$-casein gene polymorphism permits identification of bovine milk mixed with bubaline milk in mozzarella cheese. Genet. Mol. Biol., v.31, p.902-905, 2008.

RENAVILLE, R.; NICOLAS, G.; ISABELLE, P. et al. Pit-1 gene Hinfl RFLP and growth traits in double-muscled Belgian Blue cattle. J. Dairy Sci., v.75, p.146, 1997.

VELI, E.; RIVAS, E. Caracterización genética de Kappa caseínas y Beta lactoglobulinas del bovino criollo de cuatro comunidades andinas del Perú. Anim. Genet. Resour., v.46, p.67-72, 2010. 